\title{
Population Aging as the Social Body in Representation and Real Life
}

\author{
Alexandra Crampton \\ Department of Anthropology \\ Marquette University
}

\begin{abstract}
This article uses three levels of body analysis as presented by Nancy ScheperHughes and Margaret Lock to compare old age as a construct in population aging discourse with research on lived experience of people aging in the United States and Ghana. I first describe how demographers construct social bodies as becoming "gray" through population statistics and how policy makers then use dependency ratios to rationalize intervention on behalf of older adults in the body-politic. The construction of old age within this discourse is then compared with ethnographic research that suggests this construct leaves out much of the lived experience familiar to anthropologists of aging. Rather than debunk the old age construct, however, the purpose of this article is to argue for study of population aging discourse as constituting a social body reflecting cultural constructions of nature and society. Moreover, this representation is made real through policy and social intervention work, and with very real effect on people's lives. As such, an anthropology of aging bodies can include the social life of old age as a social construct.
\end{abstract}

Keywords:

\section{INTRODUCTION}

In a call for greater anthropological study of the body, Scheper-Hughes and Lock (1987) argue for examination of three, interrelated bodily forms: the body-self, the social body, and the body politic. Anthropologists of aging can most easily identify our work in the body-self when we study aging as a bodily and social experience that varies across cultural contexts (e.g. Sokolovsky 2009). The social body refers to how the physical body is used in many cultures as "good to think with" (Scheper-Hughes and Lock 1987: 18) about the nature of society. For example, drawing from Janzen (1981), Scheper-Hughes and Lock explain, "every society possesses a utopian conception of health that can be applied metaphorically from society to the body and vice versa" (Scheper-Hughes and Lock 1987,:20). The body-politic refers to how individual and social bodies (first as representations in discourse and then as live subjects) are managed through politics and social control. In this article, I argue that population aging is a social body construct through which modern, bureaucratic societies think about aging body-selves as an aggregate that can be managed and modified through social policies and social service interventions. This thinking happens through policy discourse supported by professional research and practice targeting subsets of social bodies such as children, families, and older adults. While population aging is identified by demographers as indications of successful effort to promote health and longevity (Crampton 2009; Kinsella and Phillips 2005), population aging in policy and other social intervention discourse has characterized growing segments of older cohorts as a socioeconomic problem to solve (Achenbaum 1978; Gee and Gutman 2000; Victor, Scambler, and Bond 2009). The dominant construct of old age in population aging discourse is one of individual loss and decline over 
time as a universal, singular, and inevitable experience. Chronological age is used to determine when the boundary into that state of loss is reached. This construct helps explain how populations statistically identified as aging are then characterized as "graying." The image of a populated social body that is going gray then has been used to link population aging trends to economic crisis both nationally and globally (e.g. Peterson 1999).

This representation of aging as a social problem is not only a cultural construction but also one that has been highly productive in shaping everyday lives within the body-politic. Constructs are operationalized through policy implementation and social service delivery. For example, Andrea Campbell (2011) argues that the Social Security Act in the United States helped form the social identity of older adults and helped create the social and political category of the senior citizen. At the same time, my ethnographic research from Ghana and the United States conducted in 2003, and 2004-5 suggests that the individuals represented in the social body as aging often do not identify as old and instead actively work to preserve autonomy as a mature adult. The disconnect between aging as constructed in the social body and aging as experienced by body-selves in the body-politic may help explain the responses of those in Ghana who argued that aging is "a white man's problem" in Ghana as well as those in the US who were aged sixty and over but did not identify as old and rejected aging services. As this construct is made real through social intervention work, however, it does take on a life of its own, suggesting the need to study its social life as part of and apart from that of aging selves.

The first part of this essay presents numbers and narratives of population aging discourse that form a social body subject to policy and other social intervention in the body-politic. I argue that national and global social bodies are formed through demographic statistics and given meaning through demographic transition and modernization theories. Proportionate and absolute numbers of older adults relative to working age adults are used to evaluate whether social bodies are acceptably age balanced or require intervention. Dependency ratios become assessments of whether there are enough productive adults to support young and old dependents. A social body that is unacceptably young, growing, shrinking or aging may be nationally or globally constructed as a body at risk to economic health and well-being: too many aging body-selves become a burden and a responsibility. The second part of this essay takes these assumptions as a point of inquiry in ethnographic research. How does the aging body-self as represented in the social construction of population aging compare with lived experience of aging bodies in society? The data used in this section are taken from a sixteen-month ethnographic study from 2004-5 of elder mediation programs piloted by nationally recognized elder advocacy organizations in the United States and Ghana (Crampton 2007). The finding presented in this paper is that the construct of old as frail and dependent was salient to people but actively avoided in personal experience. Even those who identified aging as a social problem located that problem more in others than in one's own body-self. These aging adults therefore avoided services for old people, while drawing from informal resources as necessary.

The concluding section provides a way to connect study of the social body constructed through population aging statistics with the lived experience of aging body-selves by examining how the representation in the former is made real in the social contexts of the latter. I argue that there is a social life to the dominant construct of old age found in the body-politic that is of ethnographic interest when operationalized through policy implementation and social service delivery. Rather than a passive embodiment of "old," people in Ghana and the United States actively engage with symbolic implications and material consequences of this construct, potentially transforming both the social meanings and objective implications of aging social bodies in the process.

\section{Methodology}

The first part of this essay analyzes population aging discourse and underlying demographic statistics learned through library research conducted for a working paper series for the Frederick S. Pardee Center for the Study of the Longer-Ranger Future (Crampton 2009), as well as academic and professional training in gerontological social work from 2001-2007. The second part of this essay is based on the ethnographic study in Ghana and the US conducted within the context of graduate training in cultural anthropology, social work, and gerontology. The research methods in each country site were similar in that each began as a qualitative program evaluation of the mediation project piloted by the elder advocacy organization selected in each country. This included immersion in the daily work of each nonprofit organization, participant observation of each program (generally beginning with some participation and then "switching hats" to a research role [see Crampton 2007]), semi-structured interviews with program participants, 
and examination of program documents and reports. In addition, methods from legal anthropology were used to "follow the ideas" (Starr and Goodale 2002, 64-5) of old age as social problem and mediation as intervention solution to better understand the underlying assumptions of each program, and how participants perceived program success and failure. Data collected included program documents, fieldnotes, and audiorecorded interviews.

As explained by Annelise Riles (2000, 2004), one challenge in conducting ethnographic work within professional and professionalized intervention networks is how to get outside the logics of the network given that anthropologists have been trained in the same ways of collecting and interpreting data. My approach to following ideas and to getting outside the network was to travel frequently among professional training, intervention, and everyday contexts with the same questions of "who is old," how is this definition constructed and by whom, and whether/how this question is salient inside and outside of each context. I asked these questions indirectly through participant observation in a range of professional and community contexts, and directly through engaging a diverse range of interlocutors. The latter included professionals who worked and did not work in the field of aging, older adults who used and did not use aging services, and formal and informal caregivers of older adults.

\section{Because my research fellowship required professional training in gerontological social work, I frequently moved from professional to informal contexts of aging within and between Ghana and the US. I also audiotaped fifteen semi-structured interviews with participants in the US pilot project, while informal engagement proved more useful with program participants in the Ghana study. For example, I conducted twenty semi- structured interviews with older adults in a Ghanaian village but the data from}

Ghana used in this essay are primarily from ethnographic fieldnotes written about informal conversations and interactions in the village (and the capital of Accra) that took place outside of more formal interviews. Informal engagement also proved useful in the US as well, and examples of strategies used by older adults outside of formal intervention were learned through immersion in US daily life. Observation of private mediation sessions and more formal, audiorecorded interviews were obtained with written consent, while informal interviews were obtained with verbal consent in order to not interrupt the flow of interaction. Data were collected with IRB approval.

\section{Representing the Social Body through Population Demographics}

\section{Numbers and Narratives}

The representation of national and international population aging is constructed through demographic statistics. Similar to the photomosaics technique (http:// www.photomosaic.com) in which an image is created from the collection of many smaller photographs, the image of a social body as young, aging or graying is formed through 
aggregate ages of individual bodyselves. The numerical image is called a population pyramid, in which each stack of the pyramid consists of a chronological cohort in five year increments. The left side of the pyramid is for males and the right side for females. Historically, the most common social body has conformed to a pyramid type shape in which the larger and younger age-stacks taper quickly to a peak representing the relatively few who live into old age (Bengston and Lowenstein, 7). Figure 1 shows how China's pyramid took this historically classic shape in 1950, and is predicted to change due to declining fertility and mortality rates.

Demographers subdivide population pyramids in order to distinguish younger and older social bodies. Age fifteen is the typical boundary between young and adult, while the boundary between adult and older adult is more fluid. International statistics typically use age sixty. However, national statistics for countries experiencing a "longevity revolution" (Butler 2000: 19) tend to use age sixty-five, while countries characterized as youthful and developing may use age fifty. One measure of population aging is when the proportion of younger individuals is shrinking, stable, or growing at a slower rate than the proportion of older adults. The popular metaphor of graying populations, then, can be misleading when the proportion of older adults is greater simply because the proportions of younger individuals is shrinking, stable, or growing at a slower rate. Demographers refer to this as "aging from below" (Vallin: 113) as pyramid bases shrink but reduced child mortality means tapering becomes less steep. Over time, aging from below produces a pyramid that is more columnar, as can be seen in Figure 1 for China in 2050.

In addition to "aging from below," populations age "from above" (Vallin:113). Population projections for Japan are one example, as shown in Figure 2. This is the trend of longevity revolution most remarkable for the numbers of older adults living into old-old ages of eighty-five and older. It is identified through proportional increases (overall numbers or rates of increase) of older adults as well as increases in life expectancy. For example, the current national leader in longevity is Monaco, with an average life expectancy at birth of eighty-nine years (CIA World Factbook 2012). Population aging from above, coupled with low fertility results in a shape has
Figure 2: Population Pyramids for Japan (Data Source: US Census Bureau, International Database)

been described as an inverted pyramid (Crampton 2009). The third most common measure of population aging foregoes the pyramid and cuts the social body in half by a calculation of mediation age. For example, the median age in China is projected to increase from age thirty-foure to forty-eight by 2050 (United Nations 2010). In other words, by 2050, half of the individual body-selves of the bodypolitic will be in their late forties or older.

How do national bodies age? Although migration does influence proportions of aging body-selves within the social body, demographers focus on fertility and mortality trends within national borders (Kinsella and Phillips 2005; Lloyd-Sherlock 2010). Demographic transition theory is used to explain how social bodies may predictably move from a youthful first stage of a triangular pyramid shape through stages of population aging. There are four stages that progress from high fertility and mortality to low fertility and mortality. According to population equilibrium theory, social bodies move through each stage and then stabilize at a level in which fertility and mortality rates balance (Vallin 2002). At this point, the demographic transition is complete. These stages reflect historic patterns of population age change as countries of the "West" (or "global North") developed and modernized. Since then, analysts use these stages as a universal model to evaluate the aging of national social bodies as predictable, too fast, stalled or reversed (Crampton 2009). An example of reversal is in Russia, where increasing male mortality contributes to population shrinkage rather than stability (Coleman 2006). Policy interventions are intended, in part, to assist social bodies in correct progression through stages, 
achievement of stable population growth, and manageable age distribution. The global spread of population aging among social bodies is regarded as a result of successful effort to improve health that then can become a problem of surplus older adults (Kinsella and Phillips 2005).

Why would greater numbers of people ages fifty, sixty or sixty-five and over require policy or service intervention? As argued by Cowgill and Holmes (Cowgill, 1974; Cowgill and Holmes 1972), the answer has been modernization theory (for more recent review, see Street and Parham 2002 or Lloyd-Sherlock 2010). While demographic transition theory is used to explain shape shifting of social bodies over time, modernization theory is used to naturalize a particular progression and universal policy prescription for social bodies going gray (Crampton 2009; Robine and Michel 2004). This theory ties the demographic statistics of aging body-selves to social, cultural, and economic contexts. The two-part stage model is a binary from traditional, youthful populations to modernized, aging populations (Cohen 1998). In traditional societies, there are comparatively few older adults who are well looked after through kinship networks. Through modernization, however, older adults might become casualties of development as younger family members move to cities in search of work, seek outside authority of formal education and professional roles, choose wage labor over hopes of inheriting family land as their main source of wealth, and lose traditional faith that associates elders with powerful ancestors. Older adults thus lose status both objectively as they lose control over valued resources, and subjectively as they become a care burden within family systems (Aboderin 2004).

The overall result is an inversion of high socioeconomic status from old to young as resources and values shift to younger adult generations. This analysis helps naturalize the historical development of retirement policies and social welfare nets for older adults in market economies. These policies and programs are now expanding to countries with much smaller social welfare states as "traveling rationalites" (Craig and Porter 2006, 120) within such policy efforts as the Madrid Plan of Action on Aging (Lane and Serour 2008). In social bodies that are becoming "old before rich" (which means population aging precedes expected economic growth, [Olshansky et. al. 2011]), solutions are found in help outside the state from nonprofit organizations (NGOs) and call for international aid. In making this argument, some scholars argue that elders are still valued and respected but that the objective problem is stress on family systems due to inadequate and uneven benefits of development (Aboderin 2004).
Younger generations travel to cities and abroad out of economic necessity and are simply unable to fulfill familial caregiving roles (ibid 2004). Older adults, whose knowledge and skills may have become out of date, are reduced to a burden on families and society.

Narratives and numbers come together in policy making through dependency ratios.

Dependency ratios compare the numbers of people working and thus actively contributing economically to the social body relative to those dependent due to age (Goldstone et. al 2012). That is, those under the age of sixteen or over sixty-five are dependent while those aged sixteen to sixty-four are productive because they should be working in the market economy (Lloyd-Sherlock 2010: 19). The use of dependency ratios helps create old age as a self perpetuating problem for the body-politic; first helping to produce problems of retirement, dependence, and exclusion by definitions used to distinguish adult from old, and then offering policy solutions to enable old people to be secure, independent, and integrated within society. This process fuels a continual need for support as more people reach the age defined and addressed in policy as dependent and in need of rescue. Carol Estes has criticized such policy and social intervention as an "aging enterprise" (Estes 2001) that marginalizes older adults and best serves professionals who build careers on fears of aging characterized by frailty, dependency, and vulnerability. John McKnight (1995) argues that the real purpose of these policies is to help younger workers compete by pushing out older workers and reducing them to consumers of gerontological expertise. As cultural artifact, this construction also embodies fears of aging as decline and loss not only to individuals but also to national populations and economies. For example, Donald Rowland describes how, "nations with the oldest populations could face the prospect of a 'demographic winter.' This would entail severe population decline and excessive aging, rather than the more hospitable 'demographic autumn' of population stability where the numbers of children and the elderly become nearly equal and constant" (Rowland 2012: 3).

\section{Dangerous Dependency Ratios in the Social Body}

Given that old age has essentially been defined in policy discourse as an antithesis to development (i.e. as unproductive and dependent), it is not surprising when policy makers regard population aging trends with alarm. Stephen Katz refers to this as "alarmist demography" (Katz 1992) while Ellen Gee and Gloria Gutman use the 
phrase "apocalyptic demography" (Gee and Gutman, 1). Within national populations, growth in older cohorts are associated with economic drain through retirement and social welfare policies (Goldstone et. al. 2012). In addition to the graying metaphor, calls for scaling back social programs have come with comparisons of older adults to natural disasters, such as an "age-quake" and "agetsunami" in mass media (e.g. Gettler 2009). Population statistics calculating dependency ratios then rationalize fear as objective assessments of economic health and well-being. Proposed policy solutions include effort to recalibrate ratios through changing the numbers of younger dependents, older dependents, or both.

Ironically, calls for policy intervention have been sounded just as population age distributions change. Before fears of a social body that was too old, population policy concern centered on fertility run amok. In the 1950s, the metaphor was of population explosion, which then drove development of family and population planning programs worldwide (Demeny and McNicoll 2006). What was unknown in 1969, when the UN Population Fund was created, was that global birth rates were peaking between 1965-1970 (Sadik 2002). Concerted policy efforts were therefore implemented just as trends began to change. Successful intervention through policy helped fuel fertility decline (Caldwell, 2002). This decline is identified as the main driver of population aging, which then brought a new fear of a "gray dawn" (Peterson, 1999) and "demographic time bomb" (Vettori 2010) thirty to forty years later. Policies for control aging trends within the social body include pronatalist policies to increase fertility, migration policy to add younger workers and families, and simply recalibrating the marker of dependency from age sixty-five to seventy in aging policies (Crampton 2009; Hudson 2009). A newer focus has been to reverse the previously assumed failings of older adults by promoting "active" and "positive" aging (Rowland 2012,:186-188). The Madrid International Action Plan on Ageing calls for "mainstreaming" older adults to reverse previous exclusion from development policy and projects (Lane and Serour 2008). As these policies continue to be proposed, the global growth in older adults is peaking, and projected by the UN to stabilize by 2050 (Börsch-Supan 2004).

\section{The Populated Social Body as Cultural Construction}

The social body as calculated through population statistics is a construction of western thinking, in which society is composed primarily of self-interested individual bodyselves who more often compete rather than cooperate with others for scarce resources. The social is simply the sum of these individuals who can be meaningfully distinguished by birthdays. The predominant construct of old age in the social body of population aging is that chronological age marks when individuals become old, and that old means frail, dependent, and vulnerable. In aging social bodies, the state has to rescue individuals and families from dependency-care burdens. State welfare and service interventions are thus produced for the good of the body-politic on behalf of older adults, families, and communities. While these interventions were first implemented in Western Europe and North America, they are increasingly applied worldwide through identification of global aging based on demographic statistics and international comparison of dependency ratios.

The predominant construct used to manage aging of the body-politic as a universal and singular problem of becoming old and dependent has long perplexed social scientists and social historians who study the everyday lives of older adults (Cohen 1994, Edmondson and von Kondratowitz 2009; Katz 2005). We know through empirical research that growing old is much more varied than facing frailty, vulnerability and dependency as an individual at a specific point in time. Multiple examples have been published from rural and urban areas (e.g. Sub-Saharan African examples in Makoni and Stroeken 2002, US examples in Kaufman 1987), in edited volumes of international research (Lynch and Danely 2013; Sokolovsky 2009) and as global comparative projects, such as The World Cities Project (Rodwin and Gusmano 2002). Arguments made thirty years ago ring familiar, today, such as this quote about aging from Östör in the 1980s, "Like time, totemism, and kinship, (aging) is based on an illusion, an assumed and interpreted universal. It is true enough as a general expectation but false as a skeleton to which cultures bring the varying appearances of flesh" (1984). The expression of "no aging" later used in this paper builds from work by Lawrence Cohen and Sarah Lamb about rejection of modernist constructions of aging in India (Cohen 1998; Lamb 2000). Yet, across cultures, social scientists have also found a common term and culturally mediated concern for when someone becomes so frail and debilitated through aging that they become totally dependent upon others (Apt, 1996; Holmes and Holmes 1995; Kertzer and Keith 1984; van der Geest 2012). The presumed utility of chronological age to mark this boundary is replaced by an empirical question of when, whether, how and why this happens to body-selves within culturally mediated social contexts in anthropological studies of aging (for research by a development specialist, see Lloyd-Sherlock, 2010). This next section draws from 
my research study comparing the construct of old age in demographic, policy, and professional intervention discourse as objective fact with old age as ethnographic question in the United States and Ghana. My interest was both in whether body-selves accepted policy and professional representation of old as reality, and what realities might this representation either distort or omit.

\section{Representation meets Reality of Who is Old in Ghana and the United States}

Before conducting pre-dissertation research on aging in Ghana during the summer of 2003, I sought research permission from the Director of the Institute for African Studies. My proposal was part of policy and professional discourse on aging in that I proposed to study aging as a bodily and social experience of those aged sixty and over. Dr. Manuh read my proposal and then simply asked, "Who is old?"

Sheflatly rejected theuseof chronologicalageorfunctional limitation. I then brought this question to colleagues, key informants, and elder mediation participants over the course of dissertation research as a way to test whether the construct of aging in population aging and other professional discourse was commonly part of every day experiences of aging. Given such a broad topic, the study focus was on a particular intervention used to address population aging as a social problem by two nationally recognized nonprofit elder advocacy organizations in two countries. The US was chosen as a country of "export" both of constructing aging as a social problem and inventing mediation as a professional intervention solution. The US is also my cultural background and I wanted to better reduce problems of internal validity (Thyer 2001, 280) by testing my assumptions of western constructions of old age against those of my fellow Americans. Ghana was chosen as a country of "import" of both aging as social problem and mediation as intervention solution. That is, research attention to population aging as a social issue in developing countries began in the 1980s (Martin and Preston 1994).

In Ghana, by the time of my research in 2004-2005, there were a growing number of nonprofit "NGO" organizations advocating on behalf of older adults, the development of a national health care policy for adults aged seventy and over, and promotion of national policy on aging (in part driven by the work of HelpAge International, based in London). At the same time, aging was identified as "a white man's problem" both for cultural reasons and greater policy concern over youth. In addition, mediation as culturally mediated response to interpersonal conflict was more widespread in Ghana than in the United States but the professionalized mediation model was regarded as a US invention. It was being imported through trainings, local legal professionals, and court reform. Thus, aging and mediation were being imported not in recognition of local realities as much as part of the geopolitics of social intervention work and international constructions of social problems and solutions. I argue that the representation of aging as social problem has had very real effects in the United States even as it does not fully represent lived experiences of aging, and that these representations are beginning to have more influence in Ghana.

In this next section, I present my argument about the relationship between old age as represented in population aging discourse and as lived experience. My data suggest that while a singular construct of old age dominates policy and intervention discourse and service delivery in each country, aging as lived experience is often an act of avoiding identification with this construct and promoting interdependencies and reciprocity over acceptance of total dependence.

\section{No Aging in the USA?}

Similar to Sharon Kaufman(1986) in the United States and "no aging" described by Laurence Cohen (1998) and Sarah Lamb (2000) in India, there was often a disconnect in my data between the construction of old age in policy, professional, and advocacy work on the one hand and everyday social meanings and practices on the other. While there was an acceptance of the construction of old as applied to others and within society as a whole, this did not necessarily extend to one's body-self. For example, an adult who signs up for Social Security and then delivers meals on wheels to seniors out of sympathy for the elderly, or a seventy year-old professional delivers a speech on the needs of older persons as the apex of a distinguished career rather than a spokesperson for this frail, vulnerable, and dependent population.

The question, "Who is old?" was thus both obvious and provocative to answer. Although sometimes taken aback, response in the US research site often started with the easy answer of bureaucratic choice, such as age sixty (as used in the Older American's Act) or sixty-five (as associated with Social Security). When resisting an easy answer, however, many stressed that old age is not a number. For example, one more formal interview respondent said, "My mother is ninety and I did not think of her as old until she had a stroke and changed quite a bit. She had 
been the kind of person who is careful to put on makeup and select what she wore before going out and she was no longer interested in that. Then, my sister and I noticed she had become forgetful." Another added that people can become old in their forties while there are others she does not consider old who are in their nineties. The difference is one of attitude and activity. Thus, "old" was defined by loss of traits identified with mature adults and as a bodily and social experience that is actively avoided. This means policy makers and professionals may often be in the awkward position of serving involuntary clients - that is, people who would rather not identify as "an official geezer." One clinical social worker explained that the hardest part of her job was convincing an older adult to accept being a client. At a senior center, a staff member described seeking older volunteers in the hope they will be more willing to later use the services themselves.

Of course, old age cannot always be avoided. In this research and other studies, however, most old people still eschewed old age services. Instead, they turned to informal services and networks. For example, one woman in her nineties relied upon neighbors, church members, and her therapist. She was afraid to live alone and yet even more afraid that social services professionals would move her to a nursing home. So, she cheerfully refused agency help as she became increasingly frail and housebound. Her preference was to place newspaper ads for people to stay with her as needed. Her informal network helped monitor the situation, and she eventually found someone who would also provide basic nursing care. Eventually, she did need formal intervention and moved to a nursing home. However, she was able to avoid this move for several years in comparison to if she had tried to live entirely independently. In her new environment, she continues to both give and receive. Although bedridden, she calls out greetings to caregivers and reads to her roommates. She does not self-identify as totally dependent.

\section{The Importance of Social Ties and Reciprocity in GHana}

As in other cultural contexts, old age in Ghana was based on whether one can support him or herself. In a laborintensive economy, this often meant being physically fit enough to work. For example, the most common response from twenty interviews conducted with older adults was that the onset of old age came when one was no longer able to contribute to one's own care or that of others. For many Ghanaians, this becomes more likely as people reach age eighty and over. Until then, many develop strategies to earn income and contribute despite aging bodies. I learned this distinction when working with a research assistant who offered to identify an interview sample of older adults. As I learned her construction of aging as limited to those who are frail, dependent, and vulnerable, and explained my study included anyone over sixty, she complained that this would include too many people and perhaps the entire village.

Proverbs are often used in Ghana to explain and enforce social norms. One focused on aging is that, "Just as the elder helped you as you cut your first teeth, so should you help them as they lose theirs." This describes a social contract. That is, one does not care for others solely as tradition; one cares for elders because of what they have done for you. Those who do not or cannot provide for children as they grow may find that there is not as much care as they grow older (see also van der Geest 2005). This is not to say there is a calculated exchange but rather that respect and love as an elder has to be deserved on some level. Barbara Stucki refers to elder strategies to manage interdependent relationships as "managing the social clock" (Stucki 1995). Many in the research study also complained that this love was more abundant in times when resources were also more abundant. In villages, children used to be routinely sent to share food with elders during harvests. This practice is less likely as resources deplete. A related comment was that old age seemed to come earlier to people today because of stressful life circumstances. At the same time. people noted that social norms have changed such that older adults cannot expect children to offer help as readily nor for younger people to seek their advice.

Overall, old age was not a particular chronological age or even state of being as much as a status negotiated within interdependent relationships. People who have "done well" and shared generously with others are more likely to enjoy their later years as ones of rest and a sense of achievement. One example is an older woman who has become the head of her extended family. This means her opinion is consulted for important matters, her presence is especially requested for special events, and her advice is sought in counseling. She has earned her elder status not only within her family but also in the village through the care she has given to others and for organizing and leading various associations. For example, she has created, "a practical approach" to what she perceives as the problem of old age in her village. She began offering help to old people after a trip to Zimbabwe taught her that Africans might otherwise turn to creating nursing homes. That is, she visits old people at home, tries to reduce family conflict that compromises elder care, lectures on reciprocity and 
care, and offers health promotion presentations. In doing this work, she has modeled the care she many need if she becomes old.

\section{Relating Representations to Realities}

In both research sites, there was an answer to the question of old age that was similar to the old age construct of decline and dependency. Yet, who was old and how one became old was more than a passive response to passing time and the aging of the body-self. Most adults aged sixty and over actively avoided identification with old age, and those who had become frail and dependent also found ways to contribute so that the relationship was also one of interdependence. This contrasts with the zero sum relationship of independent and dependent implied through dependency ratios in which a body-self is either productively working or receiving care. This also contrasts with the representation of an aging social body as constructed through population aging statistics, in which the real options and varied choices made by older adults are reduced to description of a highly stigmatized and helpless condition. Of course, as pointed out by Timothy Mitchell (2002), all representations are limited by what information has to be left out in order to provide a coherent construction. At the same time, old age as a number seems better explained by the need for clear, bounded, and mutually exclusive categories for use in statistical calculation and bureaucratic decision-making than as a proxy for the lived experience of body-selves.

The ethnographic significance of this representation is less in how real it is than in how real its impact has been. This is primarily through translation into retirement and social welfare policies coupled with service delivery for "seniors." Policy and intervention implementation across the world have re-distributed financial resources, produced new forms of knowledge (as gerontological expertise), and reinforced associations of aging with frailty and dependency. Anthropologists cannot simply dismiss a construct of old age because it is not literally true when it is made symbolically important in discourse, and then given material and social significance through policy and professional intervention. As such, old age as construct has a social life in a similar way to how Arjun Appadurai suggests we study "the social life of things" (Appadurai 1986) made politically and socially significant through culturally mediated exchange. His concept of describing the "cultural biography" of material things as they move across time and context can be usefully applied to identifying a cultural biography of old age and its relationship to the 'real' aging of body-selves in the bodypolitic.

\section{Towards a Cultural Biography of Old in the Aging Social Body}

Previous work by social historians and critical gerontologists provide groundwork for describing the cultural biography of old age as a construct (Katz 2005). They focus not as much on aging as an individual, bodyself experience as a highly social and political process. In the United States, for example, W. Andrew Achenbaum (1982) explains the importance of industrialization and subsequent labor policies of business and then government limiting the workforce beyond a certain age. During the early 20th, century, professionals also replaced older people as the experts on growing older. Correlated with this was the association of old age with decline and loss as scientific experts and technical experts promised to address problems and promote the health and well-being of elders. Acting out of genuine concern and in service to promotion of their fields, professionals convinced the general public that old age was a time of incurable disease and that long life was not necessarily the reward for living well. As a result, "new scientific theories and data forced people to reevaluate their opinions about the elderly's values in other capacities" (Achenbaum 1982) such as their own expertise on health and well-being learned through life experience. Stephen Katz (1992) traces the association of old age with disease and decline to changing policies and practices for managing the poor in the US Through reform efforts to remove and rehabilitate the able-bodied poor, the relative proportion of old people left in almshouses grew. The mainstream public then began associating old age with poverty and wasted life opportunities. Carol Estes (2001) explains how an "aging enterprise" among professionals has capitalized on fears of aging in the social body. When this is coupled with Lawrence's $(1998,94)$ observation that much of gerontological expertise has been exported from the United States and Europe through foreign policy and international conferences, a research area opens up on how the construction of old age in population aging and related discourses has taken an active role in shaping what may be a globalization of the aging enterprise. In Ghana, for example, an executive summary posted online as a government policy report on a national aging policy passed in 2010 lists several international conferences as sources of commitment to creating such policy (Government of Ghana 2010). However, the same report explains that lack of implementation had been due in part to "the apparent lack of ownership by older persons" who had not yet 
assumed their presumed role as "primary stakeholders" (ibid, 8).

My research on elder mediation programs in the United States and Ghana provides another example of intervention on behalf of older adults who may not respond as grateful clients (Crampton 2007). Neither mediation project attracted many adults over the age of sixty as old, people in need of help. Instead, interest in elder mediation in the United States has been driven by mediators seeking to expand client bases through capitalizing on population aging trends. Professionalized mediation in Ghana has been brought in through Ghanaians trained in the US and USAID funding for court reform. The specialty of elder mediation was not successful within the pilot project even as mediation continued to be used informally as a local cultural norm. In neither study site were the mediation programs able to attract older adults who sought help as frail and vulnerable adults. However, there were adults over the age of sixty in each site interested in training and practice as mediators. And, the organizations in both countries drew from population aging discourse to explain the need for services. In addition, one volunteer in the Ghanaian organization, who happened to also be over age sixty, complained of "crafty old people" who exploit agency resources by faking helplessness. In other words, old age as constructed social problem provided funding and rationale for services, and adults engaged with these programs in ways more complex than as younger providers and older (dependent) consumers. The aging enterprise may have a marginalizing impact in discourse and at the same time produce more complicated social relations and interactions in practice.

\section{Conclusion}

In this article, I use Scheper-Hughes and Lock's (1987) call for study of the social body to suggest that anthropologists seriously consider population aging as a cultural construct of anthropological interest. Demographers construct this body from population statistics, and then policymakers and other professionals use it to think about how to intervene in the body-politic. This social body is thus not only a cultural artifact providing insight into cultural constructions of the nature of society but also shapes the lives of body-selves as policies and services become part of everyday life. The driver behind this may not come from older adults themselves nor from the lived experience of getting old, and yet it still has a social reality of ethnographic interest within the body-politic. Old age as construct has a social and political history that begins in countries identified as "the west" and is now going global.
As such, it has a social life that provides a rich area for ethnographic research.

\section{References}

Aboderin, Isabella

2004. "Modernisation and Ageing Theory Revisited: Current Explanations and Recent Developing World and Historical Shifts in Material Family Support for Older People." Aging \& Society 24:29-50.

Achenbaum, W. Andrew.

1978. Old Age in the New Land. Baltimore. Johns Hopkins University Press.

Achenbaum, W. Andrew.

1982. "Further Perspectives on Modernization and Aging: A (p)review of the historical literature." Social Science History 6(3):347-368.

Appadurai, Arjun, ed.

1986. The Social Life of Things: Commodities in Cultural Context. New York: Cambridge University Press.

Apt, Nana A

1996. Coping with Old Age in a Changing Africa. Brookfield: Ashgate.

Bengston, Vern L. and Ariela Lowenstein, eds.

2003. Global Aging and Its Challenges to Families. New York: Aldine de Gruyter.

Börsch-Supan, Axel

Global Aging: Issues, Answers, More Questions. WP 2004-084. Ann Arbor, MI: University of Michigan Retirement Research Center, 2004.

Butler, Robert N. and Claude Jasmin. eds.

2000 Longevity and Quality of Life. New York: Kluwer Academic.

Campbell, Andrea

2011. How Policies Make Citizens: Senior Political Activism and the American Welfare State. Princeton: Princeton University Press.

Central Intelligence Agency World Factbook.

"Country Comparison: Life Expectancy at Birth. Accessed July 292013.

https://www.cia.gov/library/publications/the-worldfactbook/rankorder/2102rank.html 
Cohen, Lawrence.

1994. "Old Age: Culture and Critical Perspectives." Annual Review of Anthropology 27(1):137-158.

Cohen, Lawrence

1998. No Aging in India. Berkeley: University of California Press.

Craig and Porter.

2006 Development Beyond Neoliberalism? Governance, Poverty Reduction and Political Economy. New York: Routledge.

\section{Crampton, Alexandra}

"Negotiating Old Age, Mediation and Elder Advocacy in the Social Life of Helping: NGO Pilot Projects in Ghana, the US, and the Politics of Global Intervention Work." PhD diss, University of Michigan. 2007. ProQuest (Publication No. 3287495).

Crampton, Alexandra

Global Aging: Emerging Challenges. The Pardee Papers 6 . The Frederick S. Pardee Center for the Study of the Longer-Range Future, Boston University, Boston, MA, 2009. http://www.bu.edu/pardee/files/2009/09/ pardee aging-6-global-aging.pdf.

\section{Coleman, David}

2006. “Europe's Demographic Future: Determinants, Dimensions, and Challenges." Population and Development Review. 32 (S1):52-95. .

Cowgill, Donald and Lowell Holmes, eds.

1972. Aging and Modernization. New York: AppetonCenturty-Crofts.

\section{Cowgill, Donald.}

1974. "The Aging of Populations and Societies." Annals of the American Academy of Political and Social Science. 415: 1-18.

Demeny, Paul and Geoffrey McNicoll.

2006. "The Political Demography of the World System, 2000-2050." Population and Development Review 32: 254-287.

Edmondson, Ricca and Hans-Joachim von Kondratowitz. 2009. Valuing Older People: A Humanist Approach to Ageing. Bristol: The Policy Press.

Estes, Carol and Associates

2001. Social Policy and Aging: A Critical Perspective. Thousand Oaks: Sage Publications.

Gee, Ellen and Gloria Gutman

2000. The Overselling of Population Aging: Apocalyptic Demography, Intergenerational Challenges, and Social Policy. New York: Oxford University Press.
Gettler, Leon

"The Looming Age-Quake." Management Line December 18th, 2009. Accessed May 28th, 2013. http://blogs.smh.com.au/executive-style/ managementline/2009/12/18/theloomingage.html.

Goldstone, Jack, Eric Kaufmann, and Monica Toft, eds.

2002. Political Demography: How Population Changes are Reshaping National Security and National Politics. New York: Oxford University Press.

Government of Ghana and the Ministry of Employment and Social Welfare. "National Ageing Policy of Ghana," July 2010, http://www.ghanaweb.com/GhanaHomePage/ blogs/blog.article.php?blog=3442\&ID

\section{$=1000008901$.}

Hudson, Robert.

2009 "From Industrialism to Institutionalization: Theoretical Accounts of Aging Policy Development in the United States in V. Bengston (ed.) Handbook of Theories of Aging, ed. V. Bengston. (New York: Springer), 539-554.

Katz, Stephen.

1992. "Alarmist Demography: Power, Knowledge and the Elderly." Journal of Aging Studies. 6(3): 203-225.

Katz, Stephen

2005. Cultural Aging: Life Course, Lifestyle, and Senior Worlds. Ontario: Broadview Press.

Kaufman, Sharon

1986. The Ageless Self: Sources of Meaning in Late Life. Madison, WI: University of Wisconsin Press.

Kertzer, David and Jennie Keith, eds.

1984. Age and Anthropological Theory. Ithaca: Cornell University Press.

Kinsella, Kevin and David Phillips.

2005. "Global Aging: The Challenge of Success." Population Bulletin 60(1):5-42. http://www. prb.org/Publications/Reports/2005/ GlobalAging TheChallengeofSuccessPDF575KB. aspx.

Lamb, Sarah

2000. White Saris and Sweet Mangoes: Aging, Gender, and Body in North India. Berkeley: University of California Press.

Lane, Rosemary and Fatiha Serour

"The Madrid International Plan of Action on Ageing: Guiding Framework and Toolkit for Practitioners \& Policy Makers." United Nations Department of Economic \& Social Affairs Division for Social Policy \& Development. Accessed August 20, 2013, http://www. un.org/esa/socdev/ageing/documents/building natl capacity/guiding.pdf. 
Lloyd-Sherlock, Peter.

2010. Population Ageing and International Development: From Generalisation to Evidence. Bristol: The Policy Press.

Lynch, Caitrin and Jason Danely, eds.

2013. Transitions and Transformations: Cultural Perspectives on Aging and the Life Course. New York: Berghan Books.

Makoni, Sinfree and Koen Stroeken, eds.

2002. Ageing in Africa: Sociolinguistic and Anthropological Approaches. Hampshire, England: Aldershot.

Martin, Linda and Samuel Preston, eds.

1986. Demography of Aging. Committee on Population, National Research Council. Washington, D.C. http:// www.nap.edu/catalog.php?record_id=4553.

McKnight, John.

1995. The Careless Society: Community and Its Counterfeits. New York: Basic Books.

Mitchell, Timothy.

2002. The Rule of Experts: Egypt, Techno-Politics, Modernity. Berkeley: University of California Press.

Olshansky, S. Jay, Simon Biggs, W. Andrew Achenbaum, Gerald Davison, Linda Fried, Gloria Gutman, Alexandre Kalache, Kay-Tee Kaw, Alvaro Fernandez, Suresh I.S. Rattan, Renato Maia Guimaraes, Milner, and Robert N. Butler

2011. The Global Agenda Council on the Ageing Society: Policy Principles. Global Policy. 2(1).

Östör, Ákos

1984. Kertzer, David I. and Keither, Jennie. Age \& Anthropological Theory. Ithica: Cornell University Press.

Peterson, Peter.

1999Gray Dawn: How the Coming Age Wave will Transform America - and the World. New York: Three Rivers Press.

Riles, Annelise

2000. The Network Inside Out. Ann Arbor: University of Michigan Press.

Riles, Annelise.

2004. "Unwinding Technocratic and Anthropological Knowledge." American Ethnologist, Vol. 31(2): 392405. Doi:10.1525/ae.2004.31.3.392.

Robine, Jean-Marie and Jean-Pierre Michel.

2004. "Looking Forward to a General Theory on Population Aging." Journal of Gerontology: Medical Sciences 59A(6): 590-597.
Rodwin, Victor and Michael Gusmano.

2002. "The World Cities Project: Rationale, Organization, and Design for Comparison of Megacity Health Systems." Journal of Urban Health: Bulletin of the New York Academy of Medicine, 79(4): 445-463.

Sadik, Nafis, ed.

2002. An Agenda for People: UNFPA through Three Decades. New York and London: New York University Press.

Scheper-Hughes, Nancy and Margaret Lock.

1987. "The Mindful Body: A Prolegomenon to Future Work in Medical Anthropology." Medical Anthropology Quarterly 1(1): 6-41.

Sokovosky, Jay.

2009. Cultural Contexts of Aging: Worldwide Perspectives. Westport, CT: Praeger.

Starr, June and Mark Goodale. eds.

2002. Practicing Ethnography in Law: New Dialogues, Enduring Methods. New York: Palgrave Macmillan.

Street, Debra and Lori Parham.

2002. "Status of Older People: Modernization." Encyclopedia of Aging. Encyclopedia.com. Accessed May 21, 2013. http://www.encyclopedia.com/ doc/1G2-3402200387.html

Stucki, Barbara

"Managing the Social Clock: The Negotiation of Elderhood Among Rural Asante of Ghana. Thesis, Northwestern University." PhD diss., Northwestern University, 1995. ProQuest (No. AAT 9614845).

United Nations

2011. "World Population Prospects: The 2010 Revision Highlights." New York: United Nations. Accessed June 1, 2013: http://data.un.org/Data.aspx?d=PopDiv\&f= variableID $\% 3 \mathrm{~A} 41$.

Vallin, Jacques.

2002. The End of Demographic Transition: Relief or Concern? Population and Development Review 28(1): $105-120$.

Van der Geest, Sjaak.

2005. Life, Love, and Death: Conversations with Six Elders in Kwahu-Tafo, Ghana. Amsterdam: Van der Geest.

Van der Geest, Sjaak

2012 "Graceful and Successful Ageing: Observations from Ghana and the Netherlands" in Alter(n) anders denken: Kulturelle und biologische Perspektiven. ed. Brigitte Röder, Willemijn de Jong and Kurt W. Alt. Wien, Köln, Weimar: Böhlau Verlag GMBH and Cie. 
227-238. PDF. Accessed on May 28th, 2013. http:// www.sjaakvandergeest.socsci.uva.nl/pdf/ageing/ graceful 2012.pdf

Vettori, Stella, ed.

2010 .Ageing Populations and Changing Labour Markets: Social and Economic Impacts of the Demographic Time Bomb. Surrey, England: Gower.

Victor, Christina, Sasha Scambler, and John Bond 2009. The Social World of Older People: Understanding Loneliness and Social Isolation in Later Life. New York: Open University Press. 